\title{
23. PETROLOGY OF BASALTIC ROCKS COLLECTED FROM LEG 14
}

\author{
Thomas L. Wright, U. S. Geological Survey \\ W. E. Benson, National Science Foundation \\ W. G. Melson U. S. National Museum \\ S. R. Hart, Carnegie Institute of Washington
}

Basalt was recovered from four sites $(136,137,138$ and 141) drilled on Leg 14 of the Deep Sea Drilling Project. Recovered samples were originally glassy to holocrystalline basalt, now altered to varying degrees. Four of the fresher samples have been chemically analyzed. The analyses are given in Tables 1 and 2, and modes in Table 3. Table 4 summarizes the X-ray study of alteration products. A general petrographic description of each analyzed sample, based on hand specimen, optical and X-ray examination, is given below.

The results show a greater diversity of basalt types than might have been expected, ranging from low- $\mathrm{K}_{2} \mathrm{O}$ tholeiite (Site 136) through alkalic basalt (Site 138) to highly altered plagioclase porphyritic basalt of uncertain affinity (Site 137). Basalt from Site 141 is so altered that we could not determine its magmatic parentage.

\section{Site 136}

Core 9 from Site 136 consists entirely of basalt and includes one piece of solid core some 15 centimeters long and several other large core fragments that can be fitted together. A large number of smaller fragments range from a few millimeters to several centimeters across.
Most of the basalt is barely phaneritic as seen with a hand lens; grains of plagioclase and pyroxene can be distinguished. Secondary veinlets of calcite cut the core at varying angles to the long axis. Calcite also fills some of the sparse vesicles. Pyrite is associated with calcite in both veinlets and the vesicles and seems to be slightly later in origin. Pyrite is present also as disseminated grains, especially near the veinlets. Chalcopyrite is present in lesser amounts in a few of the veinlets, associated with the pyrite and calcite. Other vesicles are filled with two secondary minerals-an outer rim of dark greenish gray material and a core of light green material. None of these were seen on the thin sections and they remain unidentified. They are probably smectite judging from an X-ray study of the whole rock powder. The filled vesicles suggest that the rock is a flow rather than a sill.

A few fragments contain micropegmatite areas. Plagioclase laths are as much as 2 millimeters long, and small veinlet-like areas are coated with specular hematite. Commonly, a thin patchy film of pyrite coats the hematite.

Three thin-sections were cut from the uniform "freshlooking basalt." Two pieces of the same basalt were submitted for chemical analyses (9A and 9B, Table 1). The

TABLE 1

Chemical Analyses of Basalt, DSDP Leg 14, and Average Composition of Mid-Ocean Ridge Abyssal Basalts (Melson et al., 1968); (Column A)

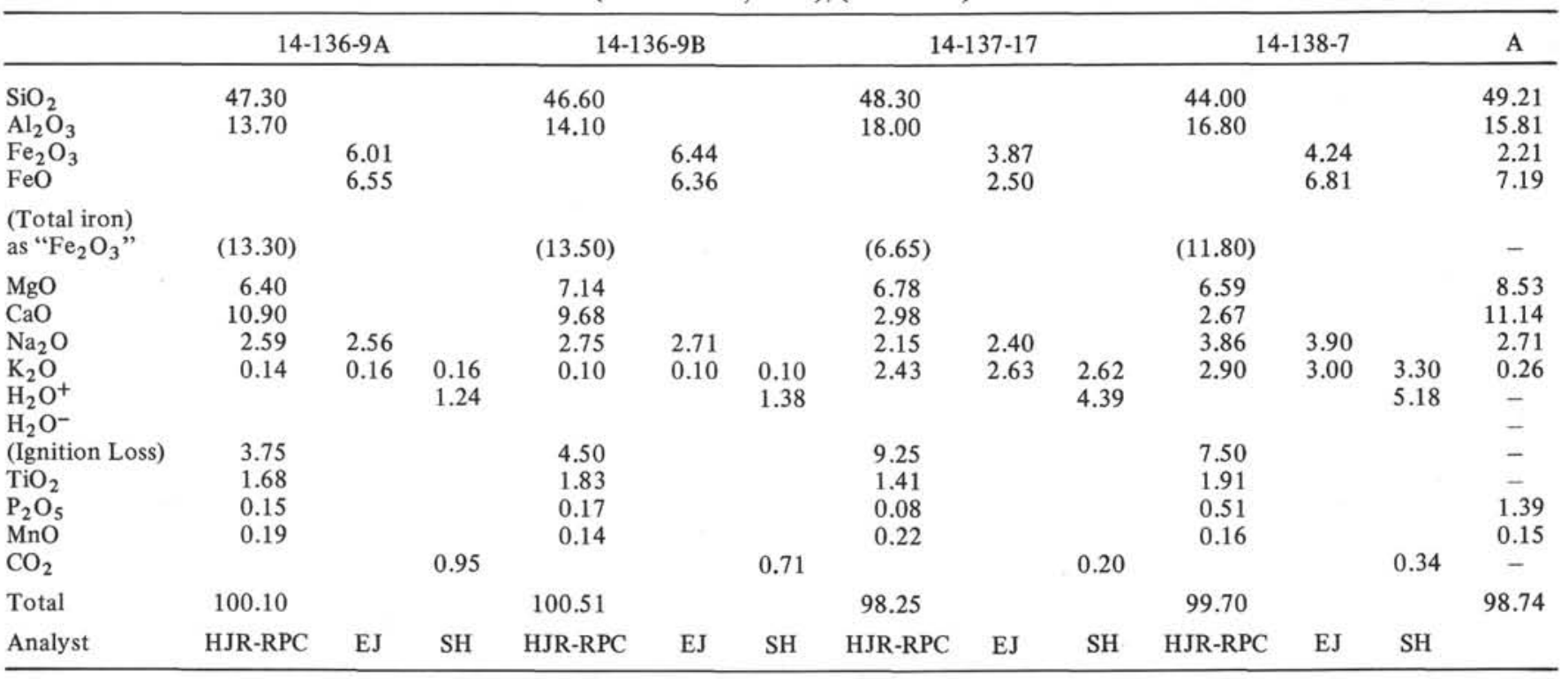

aAnalyses as follows: HJR-RPC X-ray fluorescence analyses by H. J. Rose, Jr. and Ralph P. Christian, U.S. Geological Survey; EJ. Eugene Jarosewich, Smithsonian Institution-alkalis determined by flame photometry, $\mathrm{FeO}$ by wet chemical methods, and $\mathrm{Fe}_{2} \mathrm{O}_{3}$ by difference. SH. Isotope dilution analyses by Stanley Hart, Carnegie Institution Department of Terrestrial Magnetism (see Table 2). 
TABLE 2

Concentrations of Selected Elements in Leg 14 Igneous Rocks ${ }^{\mathrm{a}}$

\begin{tabular}{lrrrr}
\hline & $136-9 \mathrm{~A}$ & \multicolumn{1}{c}{$136-9 \mathrm{~B}$} & $137-17$ & \multicolumn{1}{c}{$138-7$} \\
\hline $\mathrm{K}, \%$ & 0.134 & 0.0854 & 2.180 & 2.74 \\
$\mathrm{Rb}, \mathrm{ppm}$ & 1.420 & 0.8600 & 11.500 & 63.80 \\
$\mathrm{Cs}, \mathrm{ppm}$ & 0.008 & 0.0080 & 0.095 & 0.58 \\
$\mathrm{Sr}, \mathrm{ppm}$ & 189.000 & 198.0000 & 96.000 & 367.00 \\
$\mathrm{Ba}, \mathrm{ppm}$ & 31.800 & 27.3000 & 98.800 & 1242.00 \\
$\mathrm{H}_{2} \mathrm{O}+\%$ & 1.240 & 1.3800 & 4.390 & 5.18 \\
$\mathrm{CO}_{2}, \%$ & 0.950 & 0.7100 & 0.200 & 0.34 \\
\hline
\end{tabular}

aConcentration determined by isotope dilution and gas chromatography, generally following the techniques of Hart (1971). rock in thin section has an intergranular to subophitic texture and consists of plagioclase, pyroxene, and minor opaque oxides, set in a microcrystalline groundmass. Most of the plagioclase is in long twinned laths 0.1 to 0.75 millimeters long. A few blocky crystals show intense zoning. Average composition determined by the maximum extinction angle on (010) is An 45 (andesine) with extremes of An 60 at center and An 30 at the edge. Oscillatory zoning is common in specimen $9 \mathrm{~B}$.

The dominant pyroxene is augite, with most magnesian composition around $\mathrm{FS}_{14} \mathrm{Wo}_{38} \mathrm{En}_{49}$ and zoned toward ferro-augite and ferrohedenbergite (Figure 2). Pigeonite was
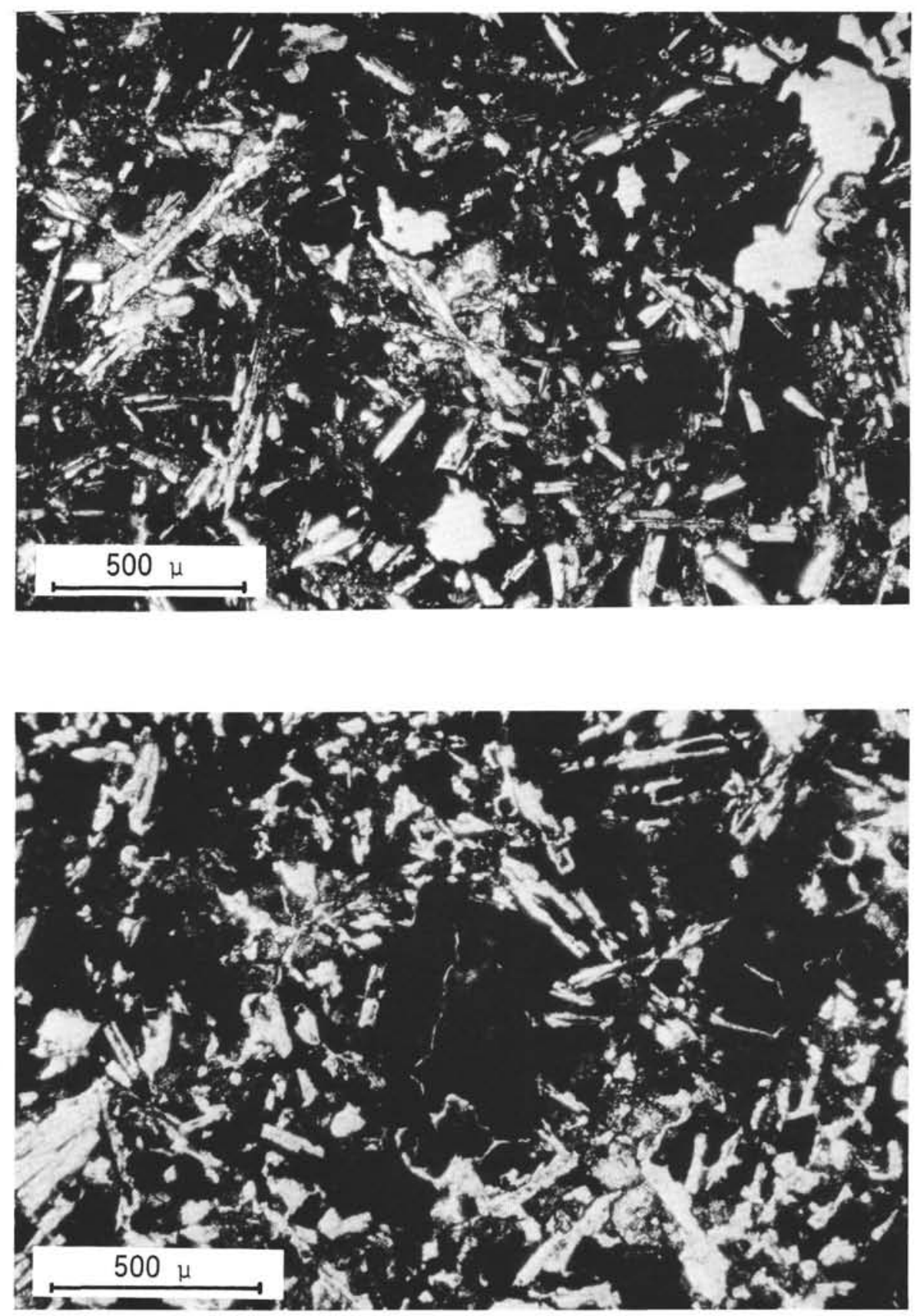

Figure 1. Basalt from Site 136 (Sample 136-9) partly albitized plagioclase in nearly opaque altered groundmass with relict pyroxene granules, oxides and other minerals. Upper photo plane light, lower photo crossed nicols (courtesy of Ulrich von Rad). 
TABLE 3

Modal Analyses (Transmitted Light) of Basalt from DSDP Leg 14

\begin{tabular}{lcccc}
\hline & $14-136-9 \mathrm{~A}$ & $14-136-9 \mathrm{~B}$ & $14-137-17$ & $14-138-7$ \\
\hline Olivine & - & $0.1(?)$ & - & $1.2^{\mathrm{c}}$ \\
Clinopyroxen $^{\mathrm{a}}$ & 15.1 & 10.4 & $\overline{\sqrt{b}}$ & 18.2 \\
Plagioclase & 32.0 & 24.2 & - & 4.6 \\
Opaque & 4.3 & 4.8 & - & 12.2 \\
Biotite & - & - & - & 7.4 \\
Chlorite & - & - & - & 1.4 \\
Epidote & - & - & - & 0.4 \\
Apatite & - & - & - & 0.2 \\
Calcite & 1.1 & 1.2 & - & $18.4^{\mathrm{d}}$ \\
Zeolite & 0.1 & - & $\overline{\sqrt{b}}$ & 36.0 \\
Altered glass & $\mathrm{e}$ & 47.5 & 60.3 &
\end{tabular}

${ }^{a} 14-136-9 \mathrm{~A}$ and $9 \mathrm{~B}$ contain a pyroxene with low birefrigence (pigeonite ?) in addition to clinopyroxene of moderate birefrigence (augite). The ratio of pigeonite (?) to augite is about 1:4 in 9A and $1: 9$ in $9 \mathrm{~B}$.

${ }^{b}$ Mode not counted. The rock consists of altered plagioclase phenocrysts in devitrified glass.

${ }^{\mathrm{c}}$ Chlorite pseudomorphs after olivine and pyroxene.

${ }^{\mathrm{d}}$ Colorless sheaves-probably altered plagioclase laths. Identified as natrolite on the whole rock X-ray pattern.

e Mainly smectite-see Table 4 .

seen in thin section but was not revealed during the electron probe survey. The pigeonite appears clearer and less altered than the augite. The groundmass (originally glass?) is now a micro-crystalline complex of fibrous "serpentine", chlorophaeite (?) and chlorite. Some of the chlorophaeite (?) areas have outlines that suggest replacement of original microlites of pyroxene or olivine. Some of
TABLE 4

Results of an X-ray Diffraction Examination in the $2 \theta$ Range $4^{\circ}-12^{\circ}$, of Five DSDP Rock Powders, Using $\mathrm{CuK} \propto$ Radiation and Oriented Slides ${ }^{\mathrm{a}}$

\begin{tabular}{|c|c|c|c|}
\hline \multirow[b]{2}{*}{ Sample Number } & \multicolumn{2}{|c|}{$\mathrm{d} \AA^{\circ}$} & \multirow[b]{2}{*}{ Mineral } \\
\hline & $\begin{array}{c}\text { Before } \\
\text { Glycolation }\end{array}$ & $\begin{array}{c}\text { After } \\
\text { Glycolation }\end{array}$ & \\
\hline $14-136-9 \mathrm{~A}$ & 13.598 & 16.673 & Smectite \\
\hline $14-136-9 B$ & 12.450 & 16.673 & Smectite \\
\hline $14-136-9 \mathrm{~A}$ & 13.598 & 16.673 & Smectite \\
\hline \multirow[t]{2}{*}{$14-138-7$} & 14.029 & 16.365 & Smectite \\
\hline & 10.048 & 10.048 & Biotite? \\
\hline 14-137-17 (bottom) & 12.627 & 16.518 & Smectite \\
\hline
\end{tabular}

${ }^{\mathrm{a}}$ Examined by Harold Banks, Smithsonian Institution.

the "serpentine" is fibrous and extends from the groundmass into grains of augite and feldspar. Other alteration products include minor saussurite and sericite along cleavage cracks of feldspar, late albite in some of the serpentinized areas, and quartz of deuteric origin. Some serpentine areas contain patches of small fibrous crystals of moderate birefringence that are probably secondary hornblende.

The major and minor element chemistry of two samples from Hole 136 (9A and 9B, Tables 1 and 2 ) is typical of spreading ridge tholeiites (for example, see Hart, 1971). The low alkali concentrations are preserved even though the $\mathrm{H}_{2} \mathrm{O}^{+}$contents are high. As the alkali elements, particularly cesium, are commonly strongly enriched during submarine weathering of basalt (Hart, 1971), it is likely that the high

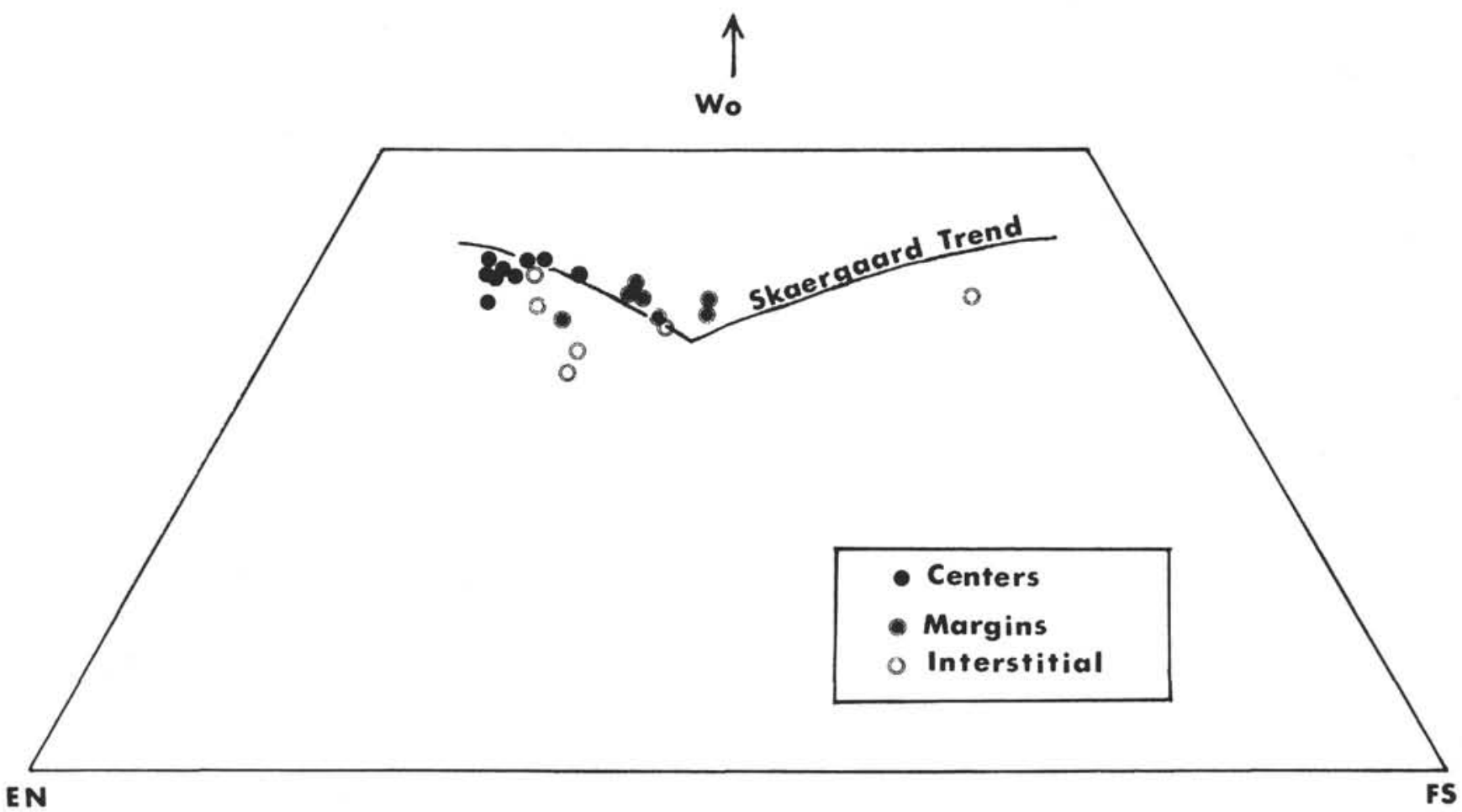

Figure 2. Pyroxene compositions in basalt from Site 136 (Sample 14-136-9) projected in the pyroxene trenary enstatite $(E N),-$ ferrosilite $\left(F_{s}\right)$ - wollastonite $($ Wo $)$. Solid line is fractionation trend of calcic pyroxenes in the Skaergaard intrusion. The pyroxenes fall close to this trend and more toward ferrozugite and hedenbergite. Some interstitial, late stage pyroxenes show a reversal to more magnesian compositions, probably reflecting extraction of $\mathrm{Fe}$ o from the melt accompanying late-stage oxidation and crystallization of magnetite. 
$\mathrm{H}_{2} \mathrm{O}^{+}$and carbon-dioxide contents are related more to deuteric alteration or low-grade metamorphism than to submarine weathering.

\section{Site 137}

Core 17 at Site 137 recovered 1.4 meters of a dark-gray brecciated igneous rock. Filling the spaces between fragments and cementing them together are veins of a darkgreen serpentine-like material that contains patches of bright red material. Thinner veins of white calcite and of a soft creamy white material also cut the rock.

In thin section the rock is seen to be highly altered; it appears to have originally been porphyritic with phenocrysts of plagioclase and minor augite in a glassy (?) base. An X-ray pattern of the whole rock shows reflections for plagioclase (with a composition near albite), natrolite, stilbite (?), and a 14A phase (smectite-see Table 4).

The major element chemistry (Table 1) also indicates a high degree of alteration. Neither the major element nor trace element chemistry (Table 2 ) suggest what the original basalt might have been.

\section{Site 138}

Two beds of alkalic basalt, about 8 meters apart, were cored at Site 138. The upper bed (Core 6, Section 2) is 50 centimeters thick. The hole bottomed in the lower bed and its thickness is unknown. A total of 120 centimeters was recovered-95 centimeters from Core 7 and 25 centimeters from the drill bit.

\section{Upper Bed}

The upper bed is a dark aphanitic greenstone with little megascopic texture. In thin section it appears as a highly altered basalt with intergranular texture. Some laths of labradorite (An 50-55) are moderately fresh, but most of the feldspar has been altered to saussurite (epidote and clinozoisite), calcite, albite and natrolite. The pyroxenes have been completely replaced by chlorite, biotite and hornblende. The groundmass, some 15 per cent of the rock, may have been glass; it is now a fine-grained intergrowth of chlorite and zeolite. Although no baked sediments were recovered either above or below the basalt, the moderate grains size (feldspars up to 0.5 millimeter), the small amount of glassy groundmass, and the 50-centimeter thickness combine combine to suggest that the bed may be a sill.

\section{Lower Bed}

The lower bed is petrographically similar to the upper, except that the grain size is slightly coarser, especially in the lower part of the cored section, and alteration is less complete. In thin section (Figure 3 ) the essential minerals are: altered plagioclase (labraderite), augite (largely pseudomorphed by chlorite) biotite and minor olivine. Accessory euhedral apatite is common. Secondary (alteration) minerals are: radiating sheaves of natrolite (positively identified by X-ray), epidote, calcite, chlorite, stilbite (?), and a potash feldspar. The groundmass is a mat of zeolite, smectite and chlorite.
The major element chemistry (Table 1) shows a definite affinity to that of alkalic basalts found on seamounts, although the alteration may have affected the original chemistry to some degree (for example, low $\mathrm{CaO}$ ). The trace element content (particularly the high barium) is also consistent with that of an alkalic basalt. Neither the petrography nor the chemistry indicates whether the lower bed is a sill or a flow.

\section{Site 141}

The rock that comprises the hard core of the "diapir" at Site 141 is a highly altered and fractured basic igneous rock, nearly black in color and largely aphanitic. Chlorite and serpentine group minerals are present but were not identified by X-ray diffraction, The rock is cut by dark green to black serpentinous veins, and, below 90 centimeters by while calcite veins. Local discrete areas of a dark green serpentinous mineral are present, especially in the lower part of the core. Spherulites are locally abundant, especially in the altered areas.

Alteration of the rock is virtually complete in all but a few slightly coarser-grained areas. In these, the rock consists of ragged laths of plagioclase (labradorite), 0.1 to 0.6 millimeter long, partly to completely saussuritized and albitized, between which are tabular areas of "serpentine" (probably chlorite plus some serpentine) that occupy the position of former pyroxene (and olivene?) grains. Surrounding both the feldspar and "serpentine" is a microcrystalline groundmass of chlorite or "serpentine", commonly dotted with "dust" of iron oxides, some of which is recognizable as hematite. In addition, there are small patches of an antigorite-like mineral with crosscutting veinlets of "serpentine" (commonly fibrous "chrysotile" sandwiching flaky "antigorite") and a few patches of chlorite. Despite the intense alteration the original sub-ophitic to intersertal texture has been preserved in many areas.

In the finer-grained areas alteration of the fledspars is nearly complete, and there is less chlorite and "serpentine". The altered rock consists largely of a fibrous mixture of albite and saussurite-prehnite with some areas of nearly pure prehnite and some of albite (Figure 4). Some of the prehnite is segregated in small spherulitic masses. "Serpentine" or chlorite is present as veinlets, small patches of micro-crystalline groundmass, and small green spherulites. Other small spherulites are filled with a white fibrous mineral, probably saponite. As in the coarser-grained areas, the "serpentine" veinlets commonly consist of fibrous "chrysotile" sandwiching a central filling of an antigoritelike mineral.

The white veins in the lower 50 centimeters of the core are nearly pure calcite with a few small veinlets of "serpentine", patches of microcrystalline "serpentine" or chlorophaeite, and a few grains of partly altered biotite and chlorite.

The rock is probably of the gabbro clan (probably basalt), nearly completely altered to a saussurite-prehnite greenstone. The alteration is probably deuteric or hydrothermal, consistent with the interpretation that this rock is the top of a volcanic plug that did not break through to the sea floor. 


\section{REFERENCES}

Melson, W. G., Thompson, G. and van Andel, Tj., 1968. Volcanism and metamorphism in the mid-Atlantic ridge. J. Geophys. Res. 73, 5925.
Hart, S. R., 1971. K, Rb, Cs, Sr, and Ba contents and Sr-isotope ratios of ocean floor basalts. Roy. Soc. London Phil. Trans., A. 268, 573.

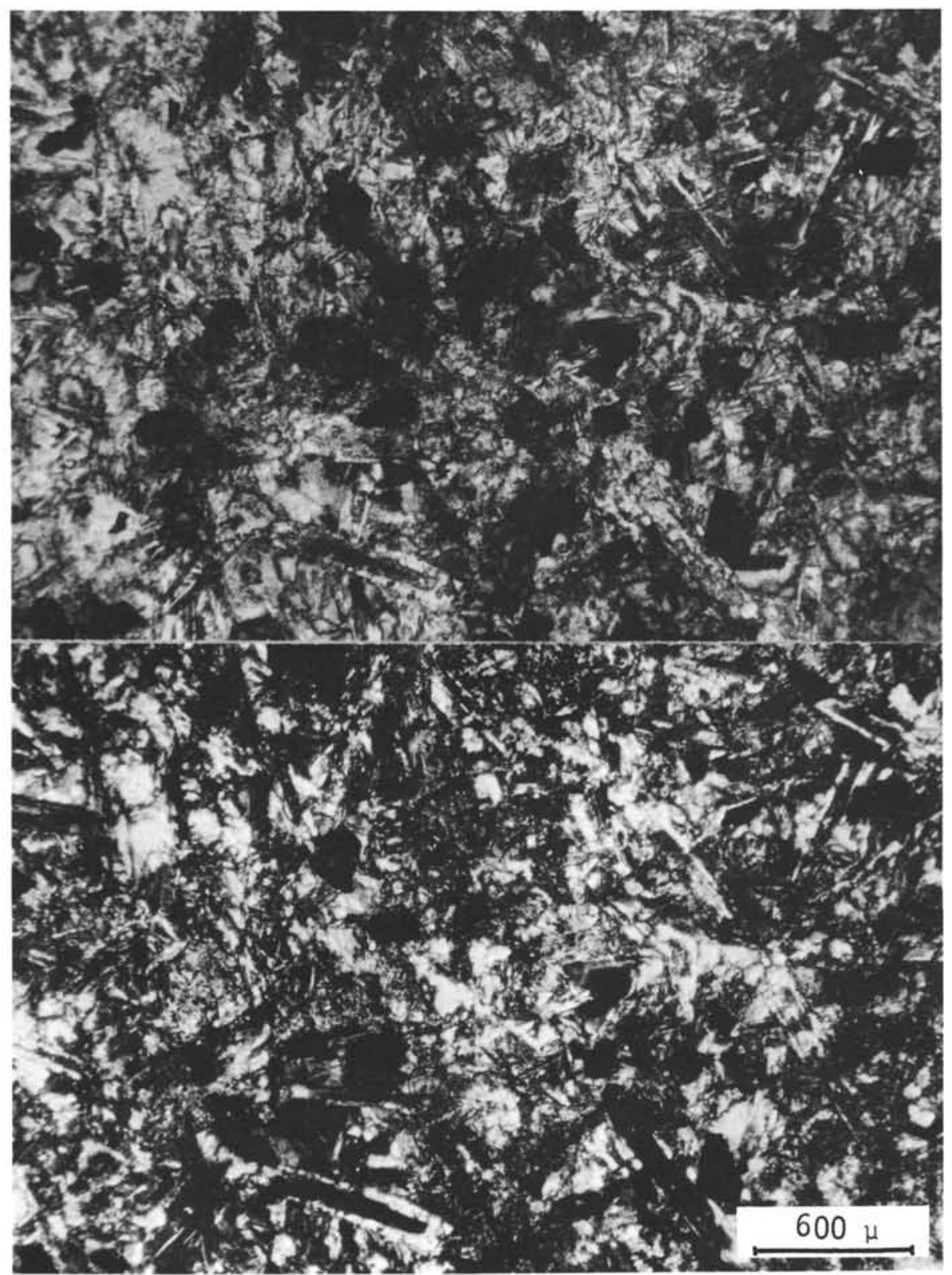

Figure 3. Highly altered "basalt" from Site 138 (Sample 138-7-1-g). Magnetite and biotite in a highly altered zeolite-rich matrix. Upper photo plane light, lower photo crossed nicols (courtesy of Ulrich von Rad). 


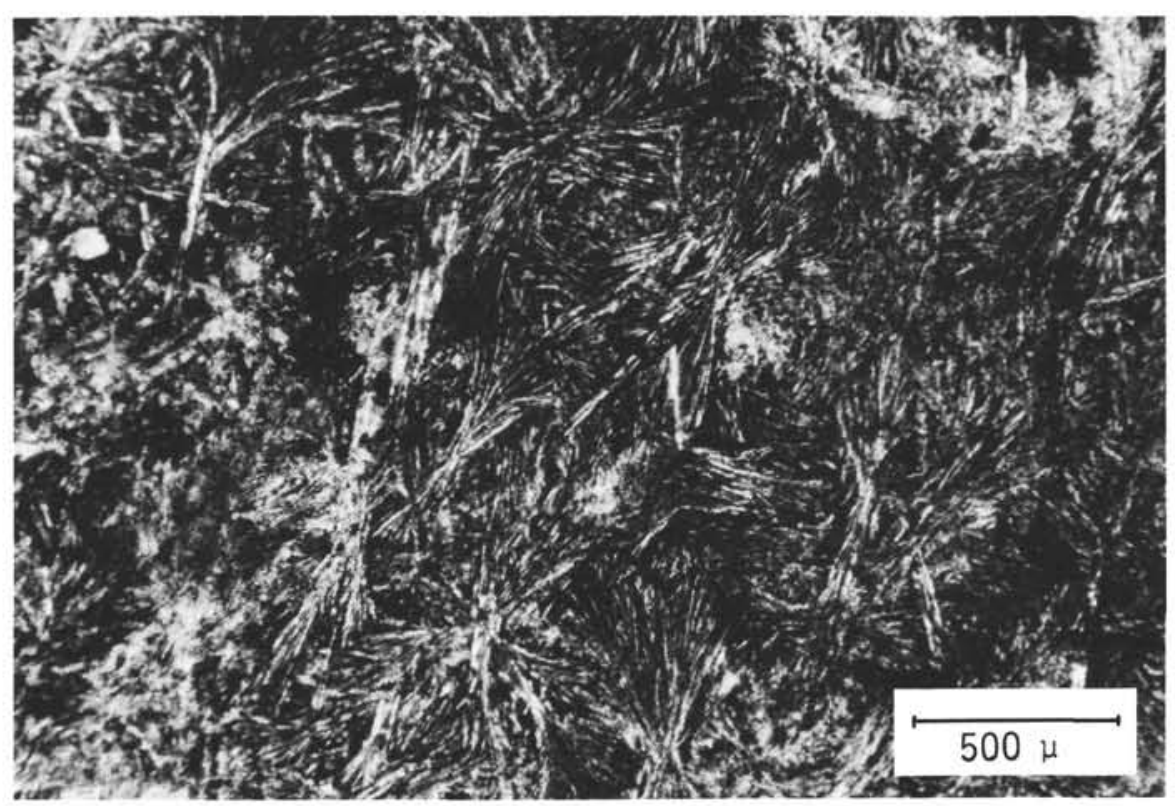

Figure 4. Highly chloritized "basalt" from Site 141 (Sample 141-10-1-50). Relict radial clusters of quenched plagioclase, largely replaced by albite and chlorite, in a highly altered matrix. 